\title{
Competitive Intelligence Practices And Performance Of Firms Listed On The Nairobi Securities Exchange, Kenya
}

\author{
Paul Waithaka \\ Department of Business Administration, Kenyatta University
}

doi: 10.19044/esj.2016.v12n19p107 URL:http://dx.doi.org/10.19044/esj.2016.v12n19p107

\begin{abstract}
Performance is critical for every listed firm, as it enhances shareholder's value and capability to generate earnings from invested capital. Some of the firms listed on the Nairobi Securities Exchange (NSE) have been performing poorly as indicated by the rising number of firms issuing profit warnings. The competitive business environment is continuously working to drive down the rate of return on invested capital. To counter these competitive forces, firms have resorted to gathering information at their disposal and converting it into competitive intelligence through analysis and human judgment. This study sought to determine the effect of competitive intelligence practices on performance of firms listed on the NSE. Firm performance was evaluated using both financial and non-financial measures. The non-financial measures used in the study were goal achievement and customer satisfaction, while Return on Assets (ROA) and Return on Equity (ROE) were the financial measures used. The target population was the sixty firms listed on the Nairobi securities exchange. Primary data was collected using a semi-structured questionnaire; while secondary data was obtained from the firm's published annual reports available at the NSE using a document review guide. Quantitative data was analyzed using both descriptive and inferential statistics. The findings indicate that competitive intelligence practices have a positive and a statistically significant effect on the non-financial performance of firms listed on the Nairobi Securities Exchange. The intelligence practices were found to have a positive but statistically insignificant effect on the financial performance of listed firms. Managers of listed firms should raise the utilization level of competitive intelligence practices to enable the firms to make accurate predictions on changes in the business environment, compete better in the marketplace against rivals, improve on innovation and automation, track competitors' activities and improve the competitiveness of their firms by identifying threats and opportunities before they become obvious. The study suggests
\end{abstract}


that future researches should focus on extending knowledge on competitive intelligence practices to non-listed corporate sector firms to support the generalization of the findings to all sectors in the economy.

Keywords: Competitive intelligence practices, strategy oriented, tactics oriented, technology oriented, target oriented and Firm performance

Firms today are experiencing an increasingly competitive environment created by globalization, advances in technology, social and economic changes as well as fast shortening product life cycle that has led to hyper-competition (Muthama \& Ngugi, 2012). Increased competition in an industry leads to lower levels of activity in organizations, hence negatively impacting on performance (Assefa, Hermes \& Meesters, 2010). While AlRfou (2012) established a positive relationship between competition and firm performance, a negative relationship cannot be ruled out in highly competitive industries (Odhiambo, Kibera \& Musyoka, 2015). The complexity in the business environment requires that managers adopt strategic management processes that they feel will facilitate the optimal positioning and performance of the firm in its competitive environment.

The competitive environment in which the firms operate makes it difficult for them to raise their level of performance and maintain a sustained competitive advantage (Shih, Liu \& Hsu, 2010). For firms to compete effectively in today's environment that is in a state of flux, there is need for advanced competencies that support strategic decision-making by providing accurate and timely information on opportunities and threats, competitor assessment that supports strategic planning and implementation, which is, after all, the main objective of competitive intelligence.

Competitive intelligence is a problem-solving process that involves information gathering and analysis, interpretation, and speculative consideration of future developments, patterns, risks and opportunities through the exercise of human judgment (McDowell, 2009). Competitive analysis forms new communication links, both inside and outside the firm. Intelligence is information that has been analyzed for strategic decisionmaking. Competitive intelligence can be viewed both as a process and a product. As a process, it is the set of legal and ethical methods for collecting, developing, analyzing and disseminating actionable information pertaining to competitors, suppliers, customers, the organization itself and business environment that can affect a company's plans, decisions and operations (Yap, Rashid \& Sapuan, 2011).

Competitive intelligence as a product is information about the present and future behavior of competitors, suppliers, customers, technologies, government, market and the general business environment (Wright, Eid \& 
Fleisher, 2009). The different products, according to Dugal (1998), are: current intelligence, basic intelligence, technical intelligence, early warning intelligence, estimates intelligence, targeted intelligence, crisis intelligence, foreign or international intelligence and counter-intelligence. Yap and Rashid (2011) indicated that other intelligence products are competitor intelligence, economic intelligence, customer intelligence and regulatory intelligence.

McGonagle and Vella (2002) identified four distinct categories of competitive intelligence practices, namely: strategy-oriented, tacticsoriented, technology-oriented and target-oriented competitive intelligence practices. The importance of the intelligence practices to an organization was found to depend on the contestability of its markets, the organizational culture and the personality and biases of its top decision-makers and the reporting structure of competitive intelligence within the company. This study adopted these practices identified by Mc Gonagle and Vella (2002), since they have widespread use in strategic management literature and have a sufficient level of abstraction to apply across a variety of organizations and industries (Shortell \& Zajac, 1990).

\section{Competitıve intelligence and firm performance}

Scholars have long argued that competitive intelligence activities are highly associated with results. Some of the arguments supporting this point suggest that competitive intelligence is a condition for survival (Vezmar, 1996); it is vital for strategy (Gieskes, 2000); it is fundamental for proactive behavior and competitive advantage (Miller, 2000); it is an absolute imperative for business (Kahaner,1997); an administrative priority (Marceau \& Sakwa, 1999); it is important for profitable and sustainable growth (Prescott \& Miller, 2001); and it is fundamental for the success of firms (Shaker \& Gembicki, 1999; Lackman, Seban\& Lanasa, 2000).

Competitive intelligence practices can be a source of sustained competitive advantage by enabling a firm to develop, implement and monitor strategies that create as well as protect shareholders' value in the long term (Protiviti, 2011). It is a valuable and performance-enhancing contributor to the process of strategy development, focused on identifying, developing and sustaining resources and capabilities that create competitive advantage. Competitive intelligence practices can make a measurable impact on both the on-going activities and long-term performance of the firm. The practices enable a firm to manage emerging opportunities and risks in a proactive manner to gain competitive advantage and enhance business performance. 


\section{Performance of firms at the nairobi securities exchange}

There are 60 companies listed on the Nairobi securities exchange (NSE, 2014). These are grouped into eleven sectors: agricultural sector; automobiles and accessories; banking, commercial and services; construction and allied; energy and petroleum; insurance, investment; manufacturing and allied; telecommunication and technology; and growth and enterprise market segment. The core function of an exchange is to ensure fair and orderly trading, as well as efficient dissemination of price information for any securities trading on that exchange (Capasso, 2006). Singh (1997) stated that stock markets are established to be a means of accelerating economic growth through increased domestic savings and improvement of the quantity and quality of investment. Security exchanges give companies, governments and other groups a platform to sell securities to the investing public.

The securities' exchange also lists treasury bonds issued by the Government of Kenya (GoK), and occasionally, there are privately issued corporate bonds as well. The level of performance is influenced by various factors, such as corporate governance, regulatory framework and the slow level of economic growth. Performance keeps alternating between bull runs when the prices for most stocks keep rising and bearish season when prices either stagnate or generally decline.

\section{Statement of the problem}

The Nairobi Securities Exchange (NSE) has been performing poorly in recent years and has not managed to make significance contribution towards accelerating the economic growth of the country (Ngugi, Amanja \& Amaana, 2009). In the recent past, there has been an increase in the number of listed firms that have been issuing profit warning. In 2011, only two out of sixty firms operating at the NSE issued a profit warning. In the financial year 2012, the number rose to ten. In the financial year 2013, thirteen companies issued profit warnings (Juma, 2014).The rising number of listed firms issuing profit warnings is an indicator of the fact that the firms are unable to sustain competitive advantage.

In Kenya, studies on competitive intelligence are generally limited and are, descriptive and case-based in nature, have been done on specific firms or industries and used profitability as the measure of performance, leaving out non-financial measures. These existing studies focused on product, market and technology intelligence according to Mugo,Wanjau \& Ayondi (2012); Ngugi \& Muthama, (2012); and Ngugi, Gakure \& Mugo (2012), this study focused on strategy-oriented, tactics-oriented, technologyoriented and target-oriented competitive intelligence practices, since these practices have a wider scope and are applicable to a variety of industries. Concerning the contextual gap among NSE listed companies and the limited 
empirical review, the study aimed to establish the effect of competitive intelligence practices on firms listed at the Nairobi securities exchange and relate it to the firms' performance, measured in both financial and nonfinancial terms.

\section{Objectives of the study}

The specific objectives of this study were:

(i)To determine the effect of strategy-oriented competitive intelligence practice on the performance of firms listed on the Nairobi Securities Exchange.

(ii)To establish the effect of tactics-oriented competitive intelligence practice on the performance of firms listed on the Nairobi Securities Exchange.

(iii)To assess the effect of technology-oriented competitive intelligence practice on the performance of firms listed on the Nairobi Securities Exchange.

(iv)To determine the effect of target-oriented competitive intelligence practice on the performance of firms listed on the Nairobi Securities Exchange.

\section{Practical implications}

Management of firms listed at the Nairobi Securities Exchange limited will gain an understanding of the extent to which competitors are utilizing competitive intelligence practices in their operations. The management of the listed firms should consider raising the current levels of competitive intelligence activities which were found to be too low to enable firms reap the benefits. The management of the listed firms should increase the amount of resources devoted to competitive intelligence activities as they were found to be low. The firms without a functional unit dedicated to competitive intelligence activities should create one to enable them cope with the changing business environment. Management of listed firms should raise utilization level of competitive intelligence practices to enable firms make more accurate prediction of environmental changes, track competitor's activities, innovate and automate process and generally improve competitiveness of listed firms.

\section{Theoretical review}

This study was underpinned by the following theories: Dynamic Capabilities Theory, Diffusions of Innovations Theory, Porter's Five Forces Model and the Resource-Based Theory. Dynamics Capability-Based Theory advocates for competing on capabilities or competencies rather than making traditional resources investments as a more appropriate method for achieving 
competitive advantage. Day and Nedungadi (1994) argue that a company should be viewed as a bundle of competencies or capabilities as well as resources. In a broad sense, capabilities refer to the organizational processes by which available resources are developed, combined, and transformed into values offered in the market. Teece, Pisano and Shuen (1997) conceptualized dynamic capabilities as idiosyncratic factors which give rise to sustainable competitive advantage.

The Diffusion of Innovations Theory explains the importance of technology intelligence in the process of identifying and exploiting scientific and technological opportunities, exerting a significant influence on the ability to innovate and is viewed as a major source of competitive advantage. The theory is normally applied to the dispersion of technical innovation over a period of time by members of a social system. Karshenas and Stoneman (1995) indicate that the three main elements of the diffusion model are: identification of stages of diffusion, characteristics of innovation that impact upon the rate of diffusion, and the adopter's strategy. The innovation decision process is a process that occurs while individuals participate in a series of actions related to decisions. In the current competitive environment, innovation is generally considered a firm's core value creation capacity and one of the most important competitive weapons (Sandvik \& Sandvik, 2003).

Porter's (1980) work on the analysis of competitive forces affecting firms, which focused on tracking specific competitor behavior and linking competitor analysis to competitive strategy, created the background for the development of competitive intelligence as a business discipline (Peyrot, Childs, Van Doren, \& Allen, 2002). Porter took a perspective of scanning the external environment to gather intelligence on competitors. Porter (1980) developed the Five Forces Model to explain the forces that shape competition in an industry. This well-defined analytical framework helps strategic managers to link remote factors and their effects on a firm's operating environment. Thompson and Strickland (2003) argued that the collective strength of these forces determines the ultimate profit potential of an industry. Whatever their collective strengths, the corporate strategists' goal should be to find a position in the industry where the firm can best defend itself against these forces or can influence them in its favour.

The Resource-Based Theory was postulated by Penrose (1959). The theory explains the main characteristics of resources that lead to competitive advantage in the market. According to this theory, resources, to a varying degree, are both significantly heterogeneous across industries and imperfectly mobile (Hunt \& Derozier, 2004). Resource heterogeneity is a condition wherein companies possess different bundles of resources in some way unique to themselves and imperfectly mobile implies that to varying degrees, they cannot be easily and readily copied, bought, or sold in the 
marketplace. Therefore, to achieve competitive advantage and, thereby, high performance, companies should seek resources that are valuable, rare, inimitable and non-substitutable. In essence, this theory suggests superior performance through enhanced competitive advantage gained by the use of unique, high value and rare organizational resources.

\section{Literature review}

Wright, Pickton and Callow (2002) examined competitive intelligence in UK firms. The study found firms with integrated procedures in which competitors are distinguished by satisfaction of customer needs, intelligence gathered through conducting primary research, information gathered and translated to strategic action, and there was an intelligence unit charged with the specific mandate and located where it would have the greatest impact. Using the findings, the researchers developed best-practice typology for effective competitive intelligence practices in an organization. The model developed in that study has been used in a number of studies, such as the study by Viviers, Saayman \& Muller (2005); the one by Wright, Eid \& Fleisher (2009; and that of Santos \& Correia, (2010).

In an investigation on the acquisition and strategic use of competitive intelligence in Malaysian listed firms, Yap \& Rashid (2011) found out that more than half of the surveyed firms had formal competitive intelligence units. The units were found to be located within the marketing or market research or corporate planning departments. It was found that on average, the units employed between two to five full-time employees and that the top source of competitive intelligence for managers were newspapers and periodicals, the internet, extranets and customers. The intelligence acquired was mostly used for making strategic decisions. The study applied the best practice model developed by Wright et al., (2002). However, concerning the identification of the top source of information, the study contradicted the findings of Wright et al., (2002), where respondents stated that the sources were determined by the type of intelligence required.

In a study that examined perceived environmental uncertainty and competitive intelligence practices, Yap, Rashid \& Sapuan (2013) found that where managers had a higher perception of environmental uncertainty, there existed a higher need for information processing. The study's findings indicated that when the business environmental sector was perceived to be variable and complex, managers tended to acquire and process information about that sector to reduce its uncertainty when making strategic decisions. The study also found that when the environmental sector was perceived to be of strategic importance and uncertain, then a greater amount of competitive intelligence was acquired and the greater the extent of the intelligence was used in strategic decision-making. The findings of this study support Zinkan 
\& Gelb (1985) who found that the use of competitive intelligence in firms largely depended on the number of competitors in the firm's external environment.

In a study examining the effect of competitive intelligence practices and firm's performance in the emerging market of India, Adidam, Shikla \& Banerjee (2012) found that Indian firms that exhibited higher levels of competitive intelligence activities achieved better financial performance and that the level of competitive intelligence activities were at a moderate level, thereby suggesting an opportunity for implementing and using more sophisticated techniques. The findings of the study support the finding of previous studies by Wee \& Leow (1994) and Hughes (2006) who found that competitive intelligence impacts positively on firm performance.

Pelsmacker, Muller, Viviers, Saayman, Cuyvers and Jegers (2005) in a study on the use of competitive intelligence practices by South African and Belgian exporters found out that to a certain extent competitive intelligence practices in the two countries were highly comparable. In both countries, there were no separate departments devoted to the competitive intelligence activities and where they existed, the activities were mostly done by marketing and sales departments. Although there were some differences, on average, managers from both countries were found to consider similar types of information important to their firms, and they relied on similar sources of information. South African companies were found to have, on average, a longer tradition of organized competitive intelligence activities and had more full-time and part-time staff involved in it. South African companies were found to devote more time to collecting information but less time to evaluating the results. In both countries, it was also found out that there was a high level of awareness of competitive intelligence and what it could do for the exporter in terms of enhancing competitiveness.

In a study to determine the effect of organizational strategy and competitive intelligence practices in Malaysian public listed companies, Yap, Zabid, \& Sapuran (2012) established that a link existed between organizational strategy and competitive intelligence practices in which a higher level of competitive intelligence acquisition in technological and economic sectors and a greater use of competitive intelligence in strategic decision-making was common among analyzers. The response rate for this study was rather low (at 10.3\%), which made the generalizability of the findings hard to assume that they apply in other firms. Noor, Waheed and Jamil (2013) examined the role of competitive intelligence in multinational companies and found out that the use of competitive intelligence had higher impact on growth and lesser on quality and organizational performance.

In a study to determine the influence of competitive intelligence practices in Essar Telcom (YU) K. Limited, Mutua (2010) noted that to cope 
with the level of competition, firms adopted strategic actions which enabled market penetration; specifically, they adopted the differentiation and innovation of products. The study found out that the players in the market had introduced cheaper but quality handsets that met the needs of the lower end of the segmented market. The firm was found to have used various competitive intelligence practices to gain understanding of the competitor's future moves, analysis of competitor's strategies, and analysis of industry players’ capability.

Muthama and Ngugi (2012) established that competitive intelligence practices played a vital role in overall profitability of mobile telecommunication companies in Kenya. The researchers found that technology intelligence was the one most utilized by these firms. The findings support April and Bessa (2006) who assert that technology is an enabler in the competitive intelligence process. The study equates competitive strategies formulated by firms to competitive intelligence practices.

Samtani and Capatina (2012) found that almost all the Romanian companies surveyed were very optimistic about the prospects for the software services industry in the future and that all seemed focused on innovation and creation of differentiated experiences for the clients. Increasing the client's efficiency and reduction of costs for doing business was found to be a top priority. Most Indian firms found that the uncertainty in the environment was affecting business growth, and innovation also featured as a way of improving efficiency and reducing costs. Most of these companies were found to have adopted aggressive strategies to make the best use of opportunities being presented by the changing environment. The big players were found to have focused on moving up the value chain while the others preferred to focus on their niche area of expertise.

Wright, Fleisher and Madden (2008) examined the characteristics of competitive intelligence practices in R\&D-driven firms in the United Kingdom pharmaceutical industry. The study found that the state of competitive intelligence practice in the industry was both fragmented and embryonic. The background of those practising competitive intelligence were found to have come largely from marketing, information and technology, and R\&D. The sources and analytical tools mostly used by practitioners were customers, suppliers and distributors. The study found that the views of both senior management and other departmental heads on the contribution of competitive intelligence to the overall performance of the firms in the industry were mixed or inconclusive. This lack of a conclusive view on the overall contribution of the competitive intelligence practice to the overall performance of firms indicated that further investigation was necessary. 
Kipkorir (2001) examined competitive intelligence practices by FM radio stations operating in Kenya. The study found that employees and majority of industry players were aware of and used competitive intelligence in trying to attain competitive advantage. To a large extent, the FM radio stations were found to use the 12P's of competitive intelligence. These stations were found to have put in place adequate training on ethical and legal guidelines for the purpose of collecting and using competitive intelligence. This study introduced a new concept of the 12 P's of competitive intelligence which seems quite rare in strategic management literature.

Gathumbi (2010) investigated the competitive intelligence practices adopted by commercial banks in Kenya. The study found that the competitive intelligence function in most banks was developed through planned action, and most employees were not extensively involved in the process. The study also found that the function was developed through project teams consisting of both employees and external consultants. This study picked on the processes of the competitive intelligence cycle and assumed them to be the competitive intelligence practices. The different variables make it hard to compare the study with a similar one by Wright et. al., (2009) on the banking industry in the United Kingdom.

Mugo, Wanjau and Ayondo (2012) found that Equity Bank employed new market intelligence, concentrating on the 4Ps of the marketing mix. Product intelligence was used to assist in aligning products to customer needs. The technology intelligence practices used by the bank were found to have an impact on profitability. The strategic alliance intelligence was found to be useful to the bank while evaluating candidates for mergers and acquisitions. While examining the competitive intelligence practices adopted by Safaricom, Wahome (2012) found that the firm employs new market intelligence as a competitive intelligence practice. This study found that the product differentiation strategies adopted by Safaricom helped to increase profitability. Other strategies included involvement of customers in product development through focused group discussions, aligning products with customer needs and the environment in which they are being offered to ensure that customers identified themselves with the firm.

\section{Research hypotheses of the study}

To examine how each of the independent variables affects the response variable, this study tested the following null hypotheses:

$\mathrm{H}_{01}$ : Strategy-oriented competitive intelligence practice has no effect on the performance of firms listed on the Nairobi Securities Exchange.

$\mathrm{H}_{02}$ : Tactics-oriented competitive intelligence practice has no effect on the performance of firms listed on the Nairobi Securities Exchange. 
$\mathrm{H}_{03}$ : Technology-oriented competitive intelligence practice has no effect on the performance of firms listed on the Nairobi Securities Exchange.

$\mathrm{H}_{04}$ : Target-oriented competitive intelligence practice has no effect on the performance of firms listed on the Nairobi Securities Exchange.

\section{Independent Variable}

\section{Dependent Variable}

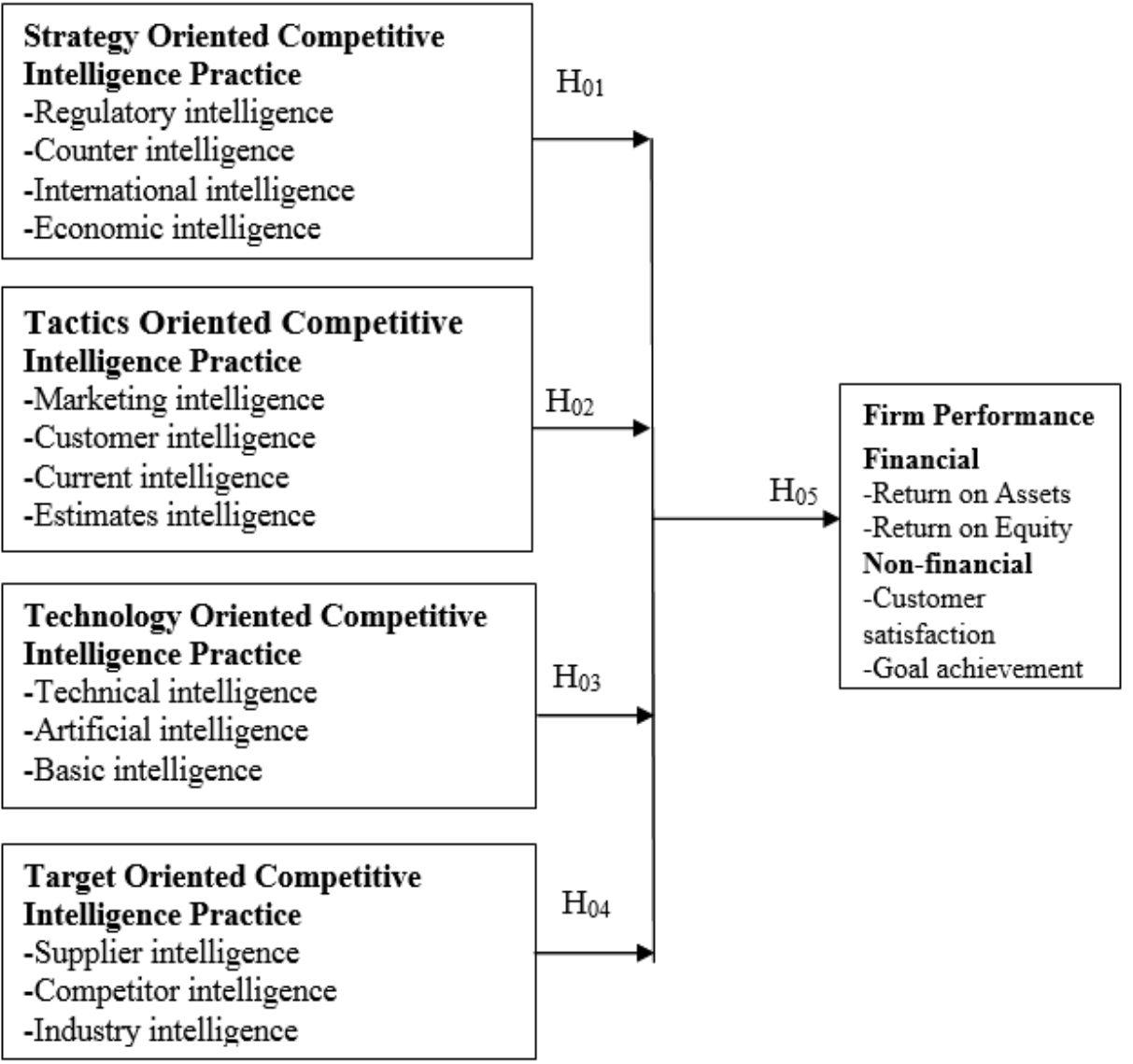

Competitive Intelligence Practices

Figure 1.1: Conceptual Framework

Source: Researcher (2016).

\section{Methodology}

The study adopted a mixed design of descriptive and explanatory survey research. According to Sekaran and Bougie (2009) a researcher should use more than one design to enhance the study; hence these two designs were used to achieve the optimal results as recommended by (Saunders, Lewis \& Thornhill, 2009). Mixed methods can elicit insights that may be overlooked by a mono-method and can produce more complete knowledge contributions to theory and practice (Niglas, 2008). 


\section{Target population}

The target population for this study were all the companies listed on the Nairobi securities exchange. There are 60 companies listed on the Nairobi securities exchange (NSE, 2014). A census study of all 60 firms listed at the Nairobi securities exchange was done. The study targeted the manager or director in-charge of planning /strategy in each firm as the unit for observation.

\section{Empirical model}

An empirical model was used to test the statistical significance of the relationship involving the five key variables, namely, strategy oriented competitive intelligence practice, tactics oriented competitive intelligence service, technology oriented competitive intelligence service, target oriented competitive intelligence practice and performance of firms listed on the Nairobi Securities Exchange. The study was guided by the Multiple Regression Model.

Performance of firms listed at the NSE

$$
\mathrm{P}=\beta_{0}+\beta_{1} \mathrm{STR}+\beta_{2} \mathrm{TAC}+\beta_{3} \mathrm{TEC}+\beta_{4} \mathrm{TAR}+\varepsilon_{\mathrm{i}} \ldots \ldots \ldots \ldots \ldots .1
$$

Where,

$P$ (for performance of firms listed on the NSE) is the dependent variable and is a linear function of $\mathrm{STR}+\mathrm{TAC}+\mathrm{TEC}+\mathrm{TAR}+\varepsilon_{\mathrm{i}}$

$\mathrm{B}_{0}$ is the intercept

$\mathrm{B}_{1-4}$ are the Beta coefficients

STR represents strategy-oriented competitive intelligence practice

TAC represents tactics-oriented competitive intelligence practice

TEC represents technology-oriented competitive intelligence practice

TAR represents target-oriented competitive intelligence practice

$\varepsilon_{\mathrm{i}}$ is a random variable, the error term that accounts for the variability in $\mathrm{P}$ that cannot be explained by the linear effect of the predictor variables.

The Models 3.2 and 3.3 below were used to determine the effect of competitive intelligence practices on the financial performance of firms listed on the Nairobi Securities Exchange:

$$
\begin{aligned}
\mathrm{ROA} & =\beta_{0}+\beta_{1} \mathrm{STR}+\beta_{2} \mathrm{TAC}+\beta_{3} \mathrm{TEC}+\beta_{4} \mathrm{TAR}+\varepsilon_{\mathrm{i}} \ldots \ldots \ldots \ldots \ldots \ldots \ldots \ldots \ldots \ldots . .3 .2 \\
\mathrm{ROE} & =\beta_{0}+\beta_{1} \mathrm{STR}+\beta_{2} \mathrm{TAC}+\beta_{3} \mathrm{TEC}+\beta_{4} \mathrm{TAR}+\varepsilon_{\mathrm{i}} \ldots \ldots \ldots \ldots \ldots \ldots \ldots \ldots \ldots .3
\end{aligned}
$$

\section{Data collection \& analysis}

Both Primary and secondary data were collected for this study. Primary data was collected from the director/manager in-charge of planning or strategy in each firm listed on the Nairobi securities exchange. Secondary data was obtained from firm's published annual reports for the years 2011 to 2013 which are available at the Nairobi securities exchange. These are the years when the number of firms issuing profit warnings rose drastically. 
Descriptive statistics such as mean scores, standard deviations, percentages, and frequency distribution were computed to describe the characteristics of the variables of interest in the study. Qualitative responses was categorized, coded and grouped into themes that emerged and then triangulated with quantitative data of the study. Inferential statistics such as correlation and regression analysis as suggested by Muthen and Muthen (2007) was used to establish the nature and magnitude of the relationships between the variables and to test the hypothesized relationships. The findings were presented using tables. Data was analyzed using SPSS version 17. A regression model was developed and correlation analysis was conducted at 95\% confidence level. Pearson's product moment correlation (r) was derived to show the nature and strength of the relationship. Coefficient of determination $\left(\mathrm{R}^{2}\right)$ was used to measure the amount of variation in the dependent variable explained by the independent variables.

\section{Findings}

Questionnaire's response rate was found to be 49 out of $60=81.6 \%$ which was very good according to (Mugenda \& Mugenda, 2003). About half the respondents 52.4\% rated information received for competitive intelligence purposes as good and excellent. Employees were found to be the most frequently used means of gathering information for intelligence purposes. Internet was ranked as the most important source of information for competitive intelligence purposes. E-mail was found to the most preferred means of dissemination competitive intelligence in the listed firms. SWOT analysis was ranked as the most preferred technique for analyzing information.

The model summary in table 1 shows R-Squared value of 0.836 , indicating that the independent variables (strategy-oriented, tactical-oriented, technology-oriented, target-oriented competitive intelligence practices) explained $83.6 \%$ variation in the non-financial performance of firms listed on the Nairobi Securities Exchange. The remaining $16.4 \%$ is unexplained and is represented by the error term. The results indicate a positive contribution of competitive intelligence practices to the performance of listed firms. The findings indicate that competitive intelligence positively affects the ability of listed firms in achieving their organizational goals and customer satisfaction.

Table 1: Model Summary of Competitive Intelligence Practices and Non-Financial Performance of Firms Listed on Nairobi Securities Exchange.

\begin{tabular}{|c|c|c|c|c|}
\hline Model & R & R Square & Adjusted R Square & Std. Error of the Estimate \\
\hline 1 & .914 & .836 & .821 & .84158 \\
\hline
\end{tabular}

Predictors: (Constant), Target oriented, Tactics oriented, Strategy oriented, Technology oriented competitive intelligence practices.

Source: Survey data 
Table 2 shows that the beta coefficients of the resulting model indicate that strategy-oriented, tactics-oriented, technology-oriented and target-oriented competitive intelligence practices (CIPs) have a positive and significant effect on the performance of firms listed on the Nairobi Securities Exchange, with slopes of $\beta_{1}=.399, \beta_{2}=.229, \beta_{3}=.150$ and $\beta_{4}=.132$ respectfully. This implies that the null hypothesis, $\beta_{1}=0$, is rejected and the alternative hypothesis, $\beta_{1} \neq 0$, is accepted.

This implies that holding all other variables constant, the nonfinancial performance of firms listed on the Nairobi Securities Exchange increase by 0.399 units when strategy-oriented competitive intelligence practice goes up by one unit, increase by 0.229 units when tactics-oriented competitive intelligence practice goes up by one unit, increase by 0.150 units when technology-oriented competitive intelligence practice goes up by one unit, and increase by .132 units when target-oriented competitive intelligence practice increases by one unit. The regression equation for the effect can be re-stated as shown:

$$
\mathrm{P}=-8.667+.399 \mathrm{STR}+.229 \mathrm{TAC}+.150 \mathrm{TEC}+.132 \mathrm{TAR}+\varepsilon
$$

The findings reveal that competitive intelligence practices play a vital role in the non-financial performance of firms listed on the Nairobi Securities Exchange. The findings contradict Wright, Fleisher and Madden (2008) who found managers in pharmaceutical industry in the United Kingdom to have mixed perception on the contribution of competitive intelligence on the overall performance on firms. The study agrees with Ain, Waheed and Jamil (2013) that companies that use competitive intelligence have a high impact on performance. The findings of the study support the finding of previous studies by Wee \& Leow (1994) and Hughes (2006) who found that competitive intelligence impacts positively on firm performance.

Table 2: Overall Regression Model Coefficients

Coefficients

\begin{tabular}{|c|c|c|c|c|c|}
\hline \multirow{2}{*}{ Model } & \multicolumn{2}{|c|}{$\begin{array}{c}\text { Unstandardized } \\
\text { Coefficients }\end{array}$} & $\begin{array}{c}\text { Standardized } \\
\text { Coefficients }\end{array}$ & \multirow{2}{*}{ Sig. } \\
\cline { 2 - 4 } & B & Std. Error & Beta & & \\
\hline (Constant) & -8.667 & 4.501 & & -1.926 & .061 \\
Strategy Oriented & .399 & .089 & .346 & 4.494 & .000 \\
Tactics Oriented & .229 & .057 & .289 & 4.026 & .000 \\
Technology & .150 & .042 & .277 & 3.535 & .001 \\
Oriented & .132 & .034 & .282 & 3.879 & .000 \\
Target Oriented & .132 &
\end{tabular}

Dependent Variable: Overall Performance

Source: Survey data

The finding indicates there is negligible improvement on the return on assets and return of equity due to the firm carrying out competitive 
intelligence activities. The study concluded that competitive intelligence practices have no statistically significant effect on the financial performance of the firms listed on the Nairobi Securities Exchange. The findings contradict Adidam (2012) who found that Indian firms that exhibited higher levels of competitive intelligence activities achieve better financial results.

\section{Conclusion}

The following conclusions were made, based on the findings of the study. The contribution of strategy-oriented competitive intelligence practice in providing higher levels of management with information on the competitive, economic, legal, and political environment in which an organization and its competitors operate, now and in the future, was found to be positive and statistically significant in the study. The practice of this type of competitive intelligence provides support for strategic decisions in the organizations, such as evaluating candidates for potential mergers, acquisitions as well as strategic alliances and partnerships. The contribution of tactics-oriented competitive intelligence that aids organizations in designing near-term plans identifiable in the marketplace was found to be positive and statistically significant in this study. This type of competitive intelligence helps a firm to track what is going on in the market where competitors face off for customers and consumers. It permits organizations to fine-tune marketing efforts and respond faster to changes in the environment.

The contribution of technology-oriented competitive intelligence practice that permits a firm to respond to threats as well as identify and exploit opportunities resulting from technical and scientific changes was found to be positive and statistically significant in this study. This type of competitive intelligence support technology- based strategies as well as research and development, which are critical for innovation in firms. The contribution of target-oriented competitive intelligence practice that permits a firm to focus on competitors, their current capabilities, current activities, plans and intentions was found to be positive and statistically significant in this study.

The effect of competitive intelligence practices was found to be positive and statistically significant. This indicates that firms that carry out competitive intelligence activities stand to gain a competitive advantage over their rivals that do not engage in the practice. The combined effect of the competitive intelligence has a positive but statistically insignificant relationship with the firm's financial Return on Assets (ROA) and Return on Equity (ROE), this means that carrying out competitive intelligence activities has no effect on the financial performance of the firms listed on the Nairobi securities exchange. 


\section{Recommendations for Policy Implications}

From the findings of this study, several policy implications can be drawn on the effective utilization of competitive intelligence in enhancing the competitive advantage of the firms listed on the Nairobi Securities Exchange over their rivals. The recommendations can also be generalized to the non-listed firms in Kenya. The policy implications are presented according to the objectives of the study.

Since strategic-oriented competitive intelligence practice was found to have a positive and significant effect on the performance of firms listed on the Nairobi Securities Exchange, the managers of these firms should consider raising the current level of competitive intelligence activities from its current relatively moderate level and start implementing more sophisticated competitive intelligence techniques and tools for analysis. This could permit the firms make accurate predictions on changes in the business environment before they become obvious as well as evaluate potential candidates for mergers, acquisitions, strategic alliances and partnerships more intelligently.

Managers of listed firms should strike a balance between long-term and short-term planning. They should ensure effective utilization of tacticsoriented competitive intelligence practice. Tactics-oriented competitive intelligence supports daily operations, such as comparing the quality and appeal of their rivals' products with their own products. This guides the sales force on the limitations and constraints of rival products and how the next generation of products might look like. The insight gained could help the sales people market the firm's products for being aware of what makes their product or service superior to that of their rival. Managers should encourage the use of this type of intelligence to gain competitive advantage at the marketplace.

The study recommends that the firms listed on the Nairobi Securities Exchange should increase their use of technology-oriented competitive intelligence to improve their competitiveness in terms of product innovation and automation to improve service delivery. Listed firms should train their employees and thus equip them with better methods of collecting and analyzing information for competitive intelligence. This would go a long way in ensuring that the firms gain competitive advantage. Target-oriented competitive intelligence practice permits a firm to seek to study its competitors, their current capabilities, current activities, plans and intentions and thus train their staff as part of making their company acquire inimitable capabilities. Firms should use target-oriented intelligence to track registration of patents by rivals and the expiry of those patents. Capital Markets Authority (CMA), the regulators of the listed firms, should 
formulate policies that ensure effective utilization of competitive intelligence so as to improve competitiveness among listed firms.

Since the study found the competitive intelligence practices to have a positive and statistically significant effect on the performance of firms listed on the Nairobi Securities Exchange, managers of these firms should increase the amount of resources devoted to competitive intelligence activities, which was found to be low compared to firms in other countries. The firms that do not have a functional unit specifically dedicated to matters of competitive intelligence should create one to enable them obtain the competitive advantage that other firms enjoy.

\section{Suggestions for Further Research}

Future research should build on the findings of this study to add to the existing body of knowledge on the practice of competitive intelligence. Such studies should, for example, consider carrying out research on the effect of competitive intelligence practices on the non-listed firms to validate this research and add more knowledge to this area of study.

\section{References:}

Al-Rfou, N. A. (2012). Competition and Organizational Performance: Empirical Evidence from Jordanian Firms, Journal of Economics, 3 (1) 13-17.

Assefa, E. Hermes, N. \& Meesters, A. (2010). Competition and Performance of Microfinance Institutions.

Adidam, P.T., Shikla, P. \& Banerjee, M. (2012).Competitive intelligence and firm's Performance in emerging market: An exploratory study in India, Journal of Business \& Industrial Marketing, 27 (3), 242-254.

April, K. \&Bassa, J. (2006). A critique of strategic competitive intelligence process within a Global Energy Multinational, Problems and Perspectives in Management, 4(2), 86-99.

Capasso, S. (2006). Stock market development and economic growth. Helsinki: World Institute for Development Economic Research.

Day, G.S. \& Nedungadi, P. (1994). Managerial representations of competitive advantage, Journal of Marketing, 58, 31-44.

Dugal, M. (1998). CI product line: a tool for enhancing user acceptance of CI.Competitive Intelligence Review, 9 (2), 17-25.

Gathumbi, A. (2010). Competitive intelligence practices adopted by Commercial Banks in Kenya. http://erepository.uonbi.ac.ke: 8080/xmlui/handle/ 123456789/22735

Gieskes, H. (2000). Competitive Intelligence at LexisNexis.CompetitiveIntelligence Review, 11 (2): 4-11. 
Hughes, S. (2006). Revise your ethics policy; Reinvigorate your program,Competitive Intelligence Magazine, 9 (2), 31-32.

Juma, V. (2014 April, 25). Home Africa sends investors profit warning. The Business Daily, Retrieved from http://www.businessdailyafrica.com

Kahaner, L., (1997), Competitive Intelligence: How to Gather Analyze and Use Information to Move Your Business to the Top. New York. Touchstone.

Karshena's, M. \& Stoneman, P. (1995).Technological diffusion in the handbook of economies of innovation and technological change, Stoneman, P. (ed). Oxford, Blackwell.

Kipkorir, S.S. (2001). Competitive intelligence practices by FM radio stations inKenya. http://erepository.uonbi.ac.ke:8080/xmlui/handle/123456789/22285

Lackman, C. L., Saban, K. \&Lanasa, J. M. (2000). The contribution of market intelligence to tactical and strategic business decisions, Market Research and Planning, 18(1), 6-8.

Marceau, S. \&Sawka, K. (1999). Developing a World-Class CI Program in Telecoms, Competitive Intelligence Review, 10, (4), 30-40.

Mc Dowell, D. (2009).A Handbook for Practitioners, Managers and Users, (Revised Edition). The Scarecrow Press. Plymouth UK.

McGonangle, J.J. \&Vella, C.M.(2002). A case for competitive intelligence, The Information Management Journal, July/August edition, 35-40.

Miller, J.P. (2000). Small business intelligence: People make it happen', in Miller, JP (Ed.) Millennium intelligence: Understanding and conducting competitive ntelligence in thedigital age. Medford, NJ, Information Today.

Muthama, T.M. \& Ngugi, K. (2012), Influence of competitive intelligence on profitability of mobile telecommunication companies in Kenya, International Journal of Innovative Research and Development,1(11).

Mugo, H. W., Wanjau, K. \& Ayodi E.M. M. (2012). An investigation into competitive intelligence practices and their effect on profitability of firms in the banking industry: A Case study of Equity Bank, International Journal of Business and Public Management, 2 (2), 61-71.

Muthen, L. K., \& Muthen, B.O. (2007).M plus User's Guide, 5th ed. Los Angeles, CA: Muthen \&Muthen.

Mugenda, O.M., \&Mugenda, A.G.(2003) . Research methods: Qualitative and Quantitative approaches. African Centre for Technology Studies. Nairobi, Kenya.

Niglas, K. (2008). How to make sense of mixed methods design? FIGSEL, Helsinki, 9-10 September.

Ngugi, J.K., Gakure R. W. \& Mugo, H. (2012). Competitive intelligence practices and their effect on profitabvility of firms in the Kenyan Banking Industry, International Journal of Business and Social Research, 2, (3),1118. 
Ngugi, J. Amanja, D. \&Amaana I. (2009). Capital market, financial deepening and economic Growth.

Noor, A. Waheed, M. \& Jamil, A. (2013).Role of competitive intelligence in Multinational Companies. International, Journal of Emerging Sciences, 3(2), 171-181.

Nairobi Securities Exchange (NSE), (2013 November 27). Retrieved November 27, 2013, fromwww.nse.org.

Odhiambo, J., Kibera, F. \&Musyoka R. (2015). Africa Management Review International Conference $20^{\text {th }}$ March, 182-195.

Pelsmacker, P. De, Muller M.L., VIviers, W., Saayman, A. Cuyvers, L. and Jegers, M. (2005). Competitive intelligence practices of South African and Belgian exporters. Marketing Intelligence and Planning, 23 (6), 606-620.

Penrose, E.T. (1959). The Theory of the growth of the Firm. New York. Wiley

Porter, M. E. (1980). Competitive Strategy, Freepress, McMillan, New York, NY.

Prescott, J.E., Miller, S.H. [eds.] (2001). Proven Strategies in Competitive Intelligence Lessons from the Trenches New York, NY: John Wiley \& Sons and Society of Competitive Intelligence Professionals.

Protiviti (2011), Maximizing the value of competitive intelligence, available at www.protiviti.com

Samtani, M. \&Capatina, A. (2012). Achieving the next level of Growth through Competitive Intelligence Practices: An Exploratory Study of Romanian Offshore Technology Service Providers. Retrieved from www.ann.ugal.ro.eco

Sandvik, I. L. \& Sandvik, K. (2003). The impact of market orientation on product Innovativeness and business performance, International Journal of Research in Marketing, 38, (9), 1091-112.

Saunders, M., Lewis, P. \&Thornhill, A. (2007).Research Methods for Business Students. $4^{\text {th }}$ ed. Harlow: Prentice Hall, Pearson Educational Limited.

Sekaran, U. \&Bougie, R. (2006). Research Methods for Business: A skills building approach, $6^{\text {th }}$ edition, John Wiley and sons.

Singh, S. (1997). Financial Liberalization stock markets and Economic Development, The Economic Journal, 107, 771-782.

Shortell, S. M., \&Zajac, E. J. (1990).Perceptual and Archival Measures of Miles and Snow's Strategic Types: A Comprehensive Assessment of Reliability and Validity. Academy of Management Journal 33, (4), 817-832. Shaker, S.M. and Gembicki, M.P. (1999).The War Room guide to Competitive Intelligence, McGraw-Hill, New York. 
Teece, D. J, Pisano, G. \& Shuen, A. (1997). Dynamic capabilities and strategic management, Strategic Management Journal, 18, (7), 509-533.

Thompson, A. A. \& Strickland, A. J. (2003). Strategic Management Concepts and Cases $-13^{\text {th }}$ ed. New York, NY, McGraw-Hill, Higher Education.

Vezmar, J.M. (1996). Competitive Intelligence at Xerox, Competitive Intelligence Review, 7(3): 15-19.

Viviers, W. Saayman, A. \& Muller M.L. (2005). Enhancing Competitive intelligence culture in South Africa. International Journal of Social Economics, 7, 576-86.

Wahome, H.W. (2012).Competitive intelligence adopted by Safaricom limited in Kenya. http://erepository.uonbi.ac.ke:8080/xmlui/handle/123456789/13731 Wee, C.H. \&Leow, M.L. (1994). Competitive business intelligence in Singapore. Journal of Strategic Marketing,2 (2),112-39.

Wright, S., Eid, E.R. \& Fleisher, C.S. (2009).Competitive intelligence in practice: Empirical evidence from the UK retail banking sector, Journal of Marketing Management, 25 (9), 941-64.

Wright, S., Picton, D.W. \& Callow, J. (2002). Competitive intelligence in UK Firms: A typology. Marketing Intelligence and Planning, 20 (6), 349360.

Yap, C. S., Zabid, Md. \&Sapuran, D. A. (2013). Strategic uncertainty and firm performance: The mediating role of competitive intelligence practices. Journal of Information and Management Systems, 12 (4).

Yap, C. S., Zabid, Md. \&Sapuran, D.A. (2012). Organizational Strategy and competitive intelligence practices in Malaysian Public listed Companies, Information Research17 (4).

Yap, C.S. \& Rashid, Z.A. (2011).Acquisition and Strategic use of competitive intelligence. Malaysian Journal of Library \& Information Science, 16 (1) April, 125-136.

Zinkhan, G. M. \& Gelb, B.D. (1985). Competitive intelligence practices for industrial marketers. Industrial Marketing Management, 14, 269-277. 